\title{
A New Social Media Freedom Podcast Construction in the Millenial Generation
}

\author{
$1^{\mathrm{st} *}$ Agus Triyono \\ Broadcasting Study Program \\ Universitas Dian Nuswantoro \\ Semaran, Indonesia \\ agustriyono7@gmail.com
}

\author{
$2^{\text {nd }}$ Arfika Pertiwi Putri \\ Broadcasting Study Program \\ Universitas Dian Nuswantoro \\ Semarang, Indonesia \\ arfika.pertiwi.putri@gmail.com
}

\begin{abstract}
The development of information technology in the media is developing very fast. One of them is a podcast that is now starting to be popular with the wider community. No exception to the millennial who began creative using this media. This research was conducted to find out how the social construction of the podcast for millennials in implementing it. Besides, to see how millennials create by using podcasts as an option in their work. Theory in this research uses the theory of freedom, social construction, and hegemony. Meanwhile, to analyze the researchers used Fairclough's critical discourse analysis to obtain the novelty of the findings. The purpose of this study is to analyze millennials in expressing new podcast media. Also, to analyze the ethical aspects carried out. The paradigm used is constructive with the type of qualitative research through the case study method. The findings of this study are media podcasts as space for millennials to express their attention and creation as extension freedom and moral freedom. However, this freedom is inseparable from social construction. there is a radical construction with soft power in a podcast which is also a media hegemony. The conclusion is that this type of new media does not yet have control in screening uploads by millennials. Also, in the end, podcasts referred to as a new free media still occur alienation of the listener as a new power relation between the listener and the producer by infusing dominant ideas into the listener.
\end{abstract}

Keywords—new media podcast, ethical foundation, millennial

\section{INTRODUCTION}

An event in the United States in October 2014 had a significant impact on the media, namely, the launch by Apple of the original podcast application that made it easier for the public to download podcasts directly to iOS mobile devices and the publication of the American storytelling spin-off show American Story (TAL) (1995-present), a podcast-first first criminal investigation named Serial [1]. The series combines the fast narrative technique led by the host TAL with the episodic delivery of the popular television format combined with the accidental emergence of Apple's podcast app, extending its appeal to a new audience outside of the already large TAL listeners. The American online community debates the ongoing mystery in forums such as Reddit, and media interest in what has been dubbed the Serial effect. The series reached one million downloads per episode in only four weeks, and by October 2015 the event had been downloaded more than 90 million times. Media attention towards postSerial saw listicles podcasts from 'Best Podcasts' is growing. The New Yorker claims that podcasting is 'humanizing the news' - humanizing the news [1].
Podcasting-as-audio-storytelling occupies a post-public radio space in the United States: 'Podcast creators, largely unregulated and independently funded, have been free to make their own rules and to try new things in ways that radio journalists do not have a public '[2]. The freedom of podcasting is the freedom to release products into the wilds of the internet and watch what happens [3]. He explained that what might make podcasting successful is not its status as a radio nuisance (as predicted by some predictions), but rather as a platform that has breathed new life, and in some cases largely forgets allusions and forms. The term 'podcasting' functionally describes the production and consumption of podcast content, which can vary. In the niche podcasts of audio stories, there is consensus that the American narrative style, which is portrayed in various ways, has a powerful influence globally and damages the popularity of older 'European' or poetic styles of audio features created [1]. The 'Chumcasts' conversation between two people is a developing format, with the potential to serve minority groups. Regions with strong public broadcasting sectors lag producing podcast formats. The US audio podcast sector is growing rapidly, and most have links to the public media ethos, but their use without compromising editorial independence remains unresolved.

In Indonesia only in 2019-2020 podcasts (Siniar) are rife to be heard and produced. Box2Box research [4] researched 18 podcasts that were played 17 million times in February 2020 as many as 1.2 million times. This survey was opened on December 26, 2019, and closed on January 17, 2020. The number of respondents collected was 2,874 users.In that study $95.4 \%$ of the listeners were male, $4.6 \%$ were female. Podcast listeners in this age range from 21-25 years reaching 50.9\%, then at the age of 26-30 years, $23.6 \%$. Podcasts are heard a lot at the time before bedtime at 21.00 as much as $37 \%$ then when returning home from $18-21$ reached $29.1 \%$. Podcasts have changed to become another alternative to be played. From Box2Box research it is known that many podcasts are listened to because on-demand (can be listened to as they like) as much as $27.82 \%$ the next reason is, to spare $22.95 \%$ and want content that varies as much as $22.86 \%$. Most of them already know what a podcast is and consider it different than radio. Spotify dominates the podcast listener market. The media used is cell phones. The majority of them are interested in attending podcast sessions live. Expect new content every Monday and/or Friday. The majority listens at home/residence. Some listen at school, campus or office. It turns out that not many listen to public transportation. They like to listen with a duration of 20-60 minutes. Even over an 
hour they still listen. That's probably why they like to listen at home; because if in a vehicle, they can only listen for less than 30 minutes and not concentrate anyway. Listeners like if there are two or more podcast speakers, one of whom can be an external speaker. The most well-liked resource is anyone who is an expert in the field of episodes or podcast themes.

Podcast has now become a new phenomenon that has become a new variant of Indonesian media. Podcasts are listened to for a variety of reasons, ranging from variations in content, listeners' fondness for a particular topic to habitual reasons of listeners who prefer to listen to read or view a show. Podcasts are then synonymous with freedom. Until now there are no regulations that specifically regulate podcasts. Freedom is a strong reason why podcasts are then popular and produced. People freely express themselves express their opinions and thoughts. However, does freedom then really exist in the ecology of podcasts? What is the other intellectual agenda born of freedom of podcasts?

\section{RESEARCH METHOD}

This research is a qualitative study using Fairclough's critical discourse analysis. About the meaning of linguistic structure, something very fundamental in the view of Fairclough [5] is the existence of the function of the relationship between textual construction with social, institutional, and ideological conditions in the processes of production and its receptions. Discourse influences social order so does social order influence discourse. First, the discourse forms and is shaped by the community. Second, discourse helps shape and change knowledge and its objects, social relations, and social identity. Third, discourse is formed by power relations and related to ideology. Fourth, the formation of the discourse marks the tug of power. Researchers used the top 6 podcasts accessed by users in Indonesia in February, namely Unfaedah podcasts, Podkesmas, Raditya Dika, Do you see what I see, podcast report cards and Hanan Attaki Study. The researcher transcribed the first 3 episodes of each podcast.

\section{RESULT AND DISCUSSION}

\section{A. Podcast Questioning Existential Freedom and Moral Freedom}

One of the strengths of podcasts is freedom of expression. This freedom refers to the absence of regulations that directly regulate podcasts. In the podcast understudy, there is a common thread of freedom to raise objections on each topic raised. The titles raised include my podcast my adventure, Beware of wealth and poverty transmitted, artists and drugs, still need to get married?, You are not alone, Azab Watching Soap Opera, Worked on Trials, My Boyfriend My Employer, What Is Podcast and No Money ?, Raising Famous Children, Dating with Pocong, Disappointed and Wisdom. From the titles in Indonesia podcasts represent several segments ranging from the freedom to discuss trivial matters, horror, everyday issues, to religious.
TABLE I. KODING 1

\begin{tabular}{|c|c|c|}
\hline Podcast & Narration & Coding \\
\hline $\begin{array}{l}\text { Artists and } \\
\text { Drugs } \\
\text { Channel: } \\
\text { Podkesmas } \\
\text { Date: } 28 \\
\text { October } 2019\end{array}$ & $\begin{array}{l}\text { Embarrassed, I went } 3 \text { days abroad } \\
\text { and didn't use "pants" (panties) ha } \\
\text { haha } \\
\text { Seriously?Ahhh embarrassing } \\
\text { I want to buy a "sempak" (underpants) } \\
\text { because it's expensive there is } \\
\text { expensive haha hahahhaa } \\
\text { Hahahahahahaha oh you're poo }\end{array}$ & $\begin{array}{l}\text { Moral } \\
\text { Freedom }\end{array}$ \\
\hline $\begin{array}{l}\text { Unfaedah } \\
\text { Podcast } \\
\text { Episode } 1\end{array}$ & $\begin{array}{l}\text { A:According to my marriage like this } \\
\text { you will be like everyone does not } \\
\text { want to be alone. There is a } \\
\text { person who wants to be alone in } \\
\text { general people do not want to be } \\
\text { alone and like a lifetime friend. } \\
\text { There is translated as a wife or } \\
\text { boyfriend forever too. } \\
\text { M: So the point is commitment, not } \\
\text { marriage legality } \\
\text { A: So, the institution will fall from the } \\
\text { strategy before, so we will explain the } \\
\text { government our system }\end{array}$ & $\begin{array}{l}\text { Existential } \\
\text { Freedom }\end{array}$ \\
\hline
\end{tabular}

Existential freedom according to [6] is total freedom that concerns the whole human person to show a uniquely human way of being, different from all other creatures. In its mechanism podcasts have existential freedom which is realized. Everyone can be himself according to what they want. Likewise, concerning the content of a podcast, it is indeed freedom to hold opinions discussing everything unconsciously. Not only in terms of content producers, content listeners also get existential freedom where they can listen to various content based on what they want. Besides, in every section of its Podcast, it is moral freedom that is inevitable. Moral freedom is when a person does not experience moral pressure or coercion. The use of diction in podcast conversations, for example, no one experiences censorship. Everyone can say in any language even in a taboo environment. Words that are censored in TV and radio media are discussed in podcasts. Freedom of use of diction in a podcast makes a podcast a land of freedom of expression, diction from various sides.

\section{B. Radical Construction and Soft Power in Indonesian Podcasts}

Social construction describes social processes through actions and interactions, where individuals create continuously something reality that is owned and experienced subjectively [7]. Social construction is closely related to human awareness of reality. Marx once explained 'false consciousness', that is the nature of human thought alienated from the actual social existence of the thinker. The podcast is nothing but a social construction formed by the producers. The reality created in a podcast is a reality created to make the listener experience false awareness. Listeners claim that they listen to podcasts because of freedom of access and content. However, the fact that freedom is said to still make them in the 'false consciousness'. They are in construction made by 
podcast producers. Alienation conditions where listeners are not aware that they have been used by podcast producers to benefit from monetization so that they get paid from their podcasts. Awareness created from listening to podcasts will then be related to their attitudes. This awareness of media creation is an awareness of social reality, where individuals become creative actors in their social reality. However, unwittingly the reality of this media creation has placed individuals outside that reality. So in other words, although the listeners of a podcast are creative actors who can listen to podcasts at anytime and anywhere, but in the end without realizing it, podcast producers have placed their listeners outside that reality.

Gramsci [7] saw that power is not always in forceful ways but is also done using 'soft power'. 'Soft power' is defined as the power to influence the awareness of others to do things according to the demands of the bourgeois class. Soft power is carried out using a continuous inculcation of ideology in the working class so that they are lulled, and want to do what is ruled by the bourgeoisie. In making podcasts there is a soft power that implements an ideology about radical modern life. Besides, podcast listeners also voluntarily share without being asked by podcast producers.

Radical social construction overrides the relationship between knowledge and reality as a criterion of truth [7]. Knowledge for them does not reflect an objective ontological reality, but rather a reality shaped by one's experience. A podcast is a radical social construction where knowledge that is not spoken of in a podcast does not use the criteria of knowledge and reality as truth criteria. The existing podcast episodes show the experience of the producers as a conversation. The topics discussed tend to be bombastic issues, but the content presented is only a conversation that sometimes has no exact essence. In some podcasts the skills of the moderator to make conclusions are weighty, but many of them also make the content only a conversation that has no conclusions. Podcast talks tend to be spontaneous and do not have a clear path.

TABLE II. KODING 2

\begin{tabular}{|c|c|c|}
\hline \multirow{2}{*}{ Podcast } & & \\
\hline & Narration & Coding \\
\hline 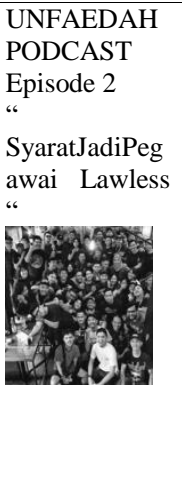 & $\begin{array}{l}\text { Semi: He was drunk, after that } \\
\text { racing he suddenly didn't know he } \\
\text { was in the pit again he drank again } \\
\text { suddenly he was called to escape } \\
\text { Jakarta garrets won weeeeyyyyy } \\
\text {....he drunk entered hold the } \\
\text { charter weeyyy...... we won so } \\
\text { Roni: (ahahaahaha) } \\
\text { Gofar: (bahahahaah) } \\
\text { Semi: } 1 \text { st place } \\
\text { Anyar: Don't win if you don't get } \\
\text { drunk }\end{array}$ & $\begin{array}{l}\text { Radical } \\
\text { Constructivism }\end{array}$ \\
\hline $\begin{array}{l}\text { Podcast: } \\
\text { Podkesmas } \\
\text { (HatiHatiKeka } \\
\text { yaan Dan }\end{array}$ & $\begin{array}{l}\text { A: I have not finished, my theory } \\
\text { goes like this that wealth has an } \\
\text { attractive magnetism because after } \\
\text { I married my wife this beautiful } \\
\text { cottage pulled me near Jagakarsa, }\end{array}$ & $\begin{array}{l}\text { Radical } \\
\text { Constructivism }\end{array}$ \\
\hline
\end{tabular}

\begin{tabular}{|c|c|c|}
\hline \multirow{2}{*}{ Podcast } & & \\
\hline & Narration & Coding \\
\hline $\begin{array}{l}\text { KemiskinanItu } \\
\text { Menular!!) }\end{array}$ & $\begin{array}{l}\text { it was quite mediocre from bekasi } \\
\text { to Jagakarsa, the theory was that } \\
\text { poverty was also contagious. } \\
\text { B: His wife who used to go to a } \\
\text { beautiful cottage turned into a } \\
\text { mansion (laughs) } \\
\text { A, B, C, D: laughing } \\
\text { C: live in a squat toilet pavilion! } \\
\text { (laughing) }\end{array}$ & \\
\hline $\begin{array}{l}\text { UNFAEDAH } \\
\text { PODCAST } \\
\text { Episode } 2 \\
\text { “ } \\
\text { SyaratJadiPeg } \\
\text { awai Lawless } \\
\text { “ }\end{array}$ & $\begin{array}{l}\text { R: Dog, what else can I do } \\
\text { A: why not eat it in a lawless } \\
\text { burger (laughter) } \\
\text { S: Because it's a lawless burger } \\
\text { wise choice (laughs) } \\
\text { M: Right, in Kemang Selatan, } \\
\text { number } 67\end{array}$ & $\begin{array}{l}\text { Soft Power, } \\
\text { False } \\
\text { Awareness, } \\
\text { Alienance }\end{array}$ \\
\hline
\end{tabular}

\section{Media Hegemony in Indonesian Podcasts}

Stuart Hall [7] argues that the mass media is the most important means of 20th-century capitalism to maintain ideological hegemony, as well as providing a framework for the development of mass culture. Through which the dominant group continually strives to maintain, institutionalize, preserve the power to undermine, weaken, and negate the potential for rivalry from the parties being controlled. The presence of a podcast does not necessarily become an alternative media which is a means to express freedom. Podcasts, in the end, remained dominated by the Jakarta bourgeoisie with all the topics discussed. According to the research podcast box 2 box, as many as $26.54 \%$ have an income of fewer than 1 million rupiahs, $26.02 \%$ earn 3 million to 6 million, and $25.18 \%$ earn between 1 million to 2 million rupiahs. That is, the listeners of the podcast are none other than those in the lower middle class.

Media hegemony emphasizes the mindset of how important the dominant group is. Through certain mechanisms of work, all forms of expression and how they are applied to influence the nature of the mind of the media, as well as the ability of the media to shape the 'agenda-setting' of society in determining cultural choices. This media hegemony then implies that the dominant group that owns the top order of podcasts in Indonesia is none other than the dominant people in Jakarta who previously had backgrounds such as artists, standup comedy, radio broadcasters. They only then expand the variety of media that is mastered not only in the mainstream media but also in alternative media such as podcasts. Especially at this time making podcasts is also a duplication of content creation from other media such as YouTube. Content that is played does not come out of dissecting their private lives as artists of their lives in the office or their private sphere. Also in the podcast, there is no interaction between the listener and the content producer. There are no comments columns and such to respond to every conversation. It is like a power relation that occurs between the listener and the producer that the absolute producer is the owner of the media without interruption or discussion. 
TABLE III. KODING 3

\begin{tabular}{|c|c|c|}
\hline Podcast & Narration & Coding \\
\hline $\begin{array}{l}\text { PODCAST } \\
\text { RADITYA } \\
\text { DIKA } \\
\text { "Podcast } \\
\text { adaduitnya?" }\end{array}$ & $\begin{array}{l}\text { Raditya Dika: } \\
\text { (laughing) It turned out that I also } \\
\text { watched a million, it was almost } \\
\text { two hours. } \\
\text { Well, at that time I began to believe } \\
\text { that the content was just chatting, } \\
\text { there were viewers in quotes on } \\
\text { Youtube. } \\
\text { I can't begin to think if I shoot on } \\
\text { Youtube why not Spotify as well }\end{array}$ & $\begin{array}{l}\text { Maintaining } \\
\text { influence, } \\
\text { media } \\
\text { hegemony }\end{array}$ \\
\hline $\begin{array}{l}\text { Podcast: } \\
\text { Podkesmas } \\
\text { My Podcast } \\
\text { My Adventure }\end{array}$ & $\begin{array}{l}\text { Darto = } \\
\text { I am a priest Darto and I have been } \\
\text { with people who took my job, first } \\
\text { Surya Insomnia has taken the } \\
\text { coment slot from me, he plays } \\
\text { smoth, he replaces danang for } 1 \\
\text { month and he approaches the } \\
\text { producer. safe? "," delicious kang } \\
\text { "," ok ", using your game," let's } \\
\text { just continue this to "wow evil you } \\
\text { sur } \\
\text { Surya =(laughing) for God's sake } \\
\text { Darto = "no noise with me to", } \\
\text { "comfortable, let's just continue to } \\
\text { the comment", "may I?" } \\
\text { Angga = severe lo sur } \\
\text { Darto = then what is wrong with } \\
\text { him, Kalikong and my password? }\end{array}$ & $\begin{array}{l}\text { Media } \\
\text { hegemony }\end{array}$ \\
\hline
\end{tabular}

The cultural ideology represented in the podcast is nothing but a metropolitan cultural ideology. The use of language with you almost dominates the top podcasts. The topics presented were not far from topics about urbanites. Hegemony is essentially an effort to lead people to assess and view social problems within the prescribed framework. In this context, Gramsci puts more emphasis on cultural aspects (ideological).
Through its products, hegemony becomes the only determinant of something that is considered both morally and intellectually right. Cultural hegemony does not only occur in relations between countries but can also occur in relations between various social classes that exist in a country. Gramsci's political theory explains how ideas or ideologies become an instrument of domination that gives the ruling group legitimacy to power. Mastery here is, of course, an intellectual power of life values ideas and a dominant metropolitan culture.

\section{CONCLUSION}

The podcast is a new media that provides freedom of expression for every user and listener. The freedom that is in the podcast is moral freedom and existential freedom. However, finally, this freedom cannot be separated as an alienation for the listener. There is a false awareness that occurs for podcast listeners who place their listeners on a reality that is outside of that reality. In a podcast, a radical social construction occurs until there is a soft power between the listener and the producer. Podcasts which are predicted as freedom remain a media hegemony dominated by a metropolitan cultural ideology which in the end is capitalism that makes money from the monetization of media podcasts. Where the more a podcast is heard, the more they will get money, which means adding to their dominant source of capital.

\section{REFERENCES}

[1] S. Mchugh and S. Mchugh, "How podcasting is changing the audio storytelling genre," no. October, 2017, doi: 10.1386/rajo.14.1.65.

[2] S. Larson, "'Serial,' Podcasts, and Humanizing the News," 2015. https://www.newyorker.com/culture/sarah-larson/serial-podcastshumanizing-news

[3] K. M. Mark, "Considerations - Reflections and Future Research. Everything Old is New Again: Podcasting as Radio's Revival, Journal of Radio \& Audio Media," J. Radio Audio Media, vol. 22, no. 2, pp. 240-243, 2015, doi: 10.1080/19376529.2015.1083376.

[4] Box2Box, "Survei pendengar siniar."

[5] Eriyanto, Analisis Wacana, Pengantar Analisis Teks Media. Yogyakarta: LKis, 2001.

[6] K. Bertens, ETIKA. Jakarta: Gramedia, 2011.

[7] B. Bungin, Konstruksi Sosial Media Massa. Bandung: Kencana Media Group, 2011. 